\title{
FEDERAL REGULATION OF DECEPTIVE PACKAGING: THE RELEVANCE OF TECHNOLOGICAL JUSTIFICATIONS
}

С into sharp focus the problem of deceptive packaging of food products. In United States v. 174 Cases of Delson Thin Mints ${ }^{2}$ the Government, under the Federal Food; - Drug, and Cosmetic Act, ${ }^{3}$ instituted a proceeding $\$$ to seize and condemn certain cartons of thin mints. The Government charged that the packages were'misbranded within the meaning of section $403(\mathrm{~d})$ of the act because they were "so . . . filled as to be misleading" to a prospective purchaser. ${ }^{5}$ Each package was divided into three compartments by means of hollow cardboard dividers, and each end of the package consisted of a hollow re-

*180 F. Supp. 863 (D.N.J. 1960), vacated, 287 F.2d 246 (3d Cir. 1961), on remand, 195 F. Supp. 326 (D. N.J.J. 1961), aff'd per curiam, 302 F.2d 724 (3d Cir. 1962).

1. Hearings on Packaging and Labeling Practices Before the Subcommittce on Antitrust and Monopoly of the Senate Committee on the Judiciary, 87th Cong, 1st \& 2d Sess. (1961-62) [hereinafter cited as Packaging Hearings].

2. 180 F. Supp. 863 (D.N.J. 1960), vacated, 287 F.2d 246 (3d Cir. 1961), on remand, 195 F. Supp. 326 (D.N.J. 1961), aff'd per cutriam, 302 F.2d 724 (3d Cir. 1962).

3. 52 Stat. 1040 (1938), as amended, 21 U.S.C. $\S \S 301-92$ (1958).

4. Section 304(a), 52 Stat. 1044 (1938), as amended, 21 U.S.C. $\S 334(a)$ (1958) provides that

Any article of food ... that is ... misbranded when introduced into or while in interstate commerce ... shall be liable to be proceeded against while in interstate commerce, or at any time thereafter, on libel of information and condemned in any district court of the United States within the jurisdiction of which the article is found....

5. Section 301(b), 52 Stat. 1042 (1938), 21 U.S.C. $\S 331$ (b) (1958) prohibits the "... misbranding of any food ... in interstate commerce."

Section 403(d), 52 Stat. 1047 (1938), 21 U.S.C. \& 343(d) (1958) states that a food shall be deemed to be misbranded "[i]f its container is so made, formed, or filled as to be misleading." The legislative history of this provision is discussed in Depew, The SlackFilled Package Law, 1 Food Drug Cosm. L.J. 86 (1946) and Martin, Section 403(d)Containers So Made, Formed, or Filled as to Be Misleading, 8 Food Drug Cosm. L.J. 663 (1953). The complete legislative history of the Federal Food, Drug, and Cosmetic Act is contained in Dunn, Federal. Food, Drug, and Cosmetic Act (1938).

FDA activity to enforce $\S 403$ (d) is detailed in the annual reports contained in Foov Law Institute Series, Federal Food, Drug, and Cosaretic Law Aduinistrative RePORTS 1907-1949 (1951) and, since the creation of the Department of Health, Education, and Welfare, in the ANNUAL REPORTS of the latter.

Endeavors by the FDA to enforce section 403(d) have involved the courts only three times prior to Delson. United. States v. Cataldo, 157 F.2d 802 (1st Cir. 1946); United States v. 116 Boxes of Arden Assorted Candy Drops, 80 F. Supp. 911 (D. Mass. 1948); United States v. 738 Cases of Jiffy-Lou Vanilla Flavor Pudding, 71 F. Supp. 279 (D. Ariz. 1946). For a discussion of these cases, all of which were lost by the Government, see Martint, supra. These three FDA defeats were partly responsible for the decrease in attention which $\S 403$ (d) received during the 1950's. See Larrick, Some Comments on Packaging, 17 Food Drug CosM. L.J. 442, 444 (1962). 
cess. Although the mints occupied only 45 per cent of the volume, ${ }^{6}$ the manufacturer denied that its packages were either intended to or in fact did deceive the public. It argued that the design of the container was adopted to provide an economical package which would give adequate protection to the fragile mints. ${ }^{7}$ On appeal from the district court's dismissal of the libel, ${ }^{8}$ the Court of Appeals for the Third Circuit, holding that the lower court's judgment was not supported by the necessary findings, stated two alternative ways that a trial court might hold for a claimant:

First, the court can find as a fact that the accused package is not made, formed, or filled in such a way that it would deceive the ordinary purchaser as to the quantity of its contents. ... Alternatively, the court may find as a fact that even though the form or filling of the package deceives the ordinary purchaser into thinking that it contains more food than it actually does, the form and filling of the package is justified by considerations of safety and is reasonable in the light of available safety features. ${ }^{\circ}$

6. The trial court described the mints as "circular in shape, having one side slightly" convex and the opposite side flat." $180 \mathrm{~F}$. Supp. at 865 . Each of the three compartments in the package contained ten mints. Some of the space in the rectangular box would necessarily be empty because of the shape of the mints, but at the trial a Government witness showed that it was possible, by removing the hollow ends and dividers and substituting single thicknesses of cardboard, to add elever mints to the box. Id. at 866 . On remand, the trial judge found that three more mints could be added to the box even with the hollow dividers. 195 F. Supp. at 327.

7. The evidence on this issue was clearly in conflict. An expert witness testified on the claimant's behalf that, in his opinion, the hollow partitions and ends were intended for and did achieve protection of the contents against shock. $180 \mathrm{~F}$. Supp. at 867 . On the other hand the record contained substantial Government evidence to the effect that the Delson box was no more effective than other types of cartons which contained less empty space. Brief for Appellant, pp. 16-20, United States v. 174 Cases of Delson Thin Mints, 302 F.2d 724 (3d Cir. 1962).

8. The court stated that the case lacked "adequate proof that the average adult, of normal intelligence, would be induced by the exterior appearance of the accused containers to buy a box of Delson mints with the expectation that it would contain any particular number of individual candies." $180 \mathrm{~F}$. Supp. at 868 . The court also found that the container was "efficacious to a degree for . . . protective purposes . . . ." Id. at 867. Mforeover, the court was persuaded that "the exigencies of machine filling, handling and shipping of sep3rate pieces of candy ... require that less than the total interior volume of the box in which they are contained be occupied by the candies." Id. at 868. It is perhaps worth noting that the Delson packages were hand filled; only the wrapping of the packages was done by machine. 195 F. Supp. at 329.

9. $287 \mathrm{~F} .2 \mathrm{~d}$ at 247 . The Court of Appeals further stated that the trial court's finding with respect to consumer expectations (note $8 \mathrm{supra}$ ) was "beside the point. The question was not whether the ordinary purchaser would expect to find a parlicular mumber of individual candies in the box but whether such a purchaser would expect to find more of the Delson box filled." Ibid. (Emphasis added.) Referring to the trial court's finding that the container was "efficacious to a degree" (note 8 sipra), the Court of Appeals stated: "[T]his [finding] is not enough. The court has to find that the container's efficacy outweighs its deceptive quality. Further, it has to find that the available alternative efficacious means are not less deceptive than those actually employed." Id. at 248.

On the remand, the district court made, inter alia, the following findings of fact: (1) "The accused package is not so made, formed, or filled as to deceive the ordinary purchaser 
This decision represents the first in which a court has held that a defense based upon technological considerations may be available to a claimant whose packages are found to be deceptive.

Congressional motivation for the passage of section 403(d) appears in part to have been a desire to prevent an economic injury to the consumer. Senator Copeland, one of the sponsors of the 1938 food and drug legislation, offered as an example of offensive packaging a carton of cheese which appeared to be full but in fact contained one layer of cheese and a pasteboard bottom occupying most of the container. "The housewife," he said, "has been robbed. ..."10 The Senator seems to have been suggesting that if a purchaser is confronted with two similarly priced cartons of cheese, one somewhat larger than the other, her decision to purchase the larger carton may to some extent be based on quantitative expectations aroused by its size. Yet, if the larger carton is slack-filled and actually contains less cheese than the smaller carton, the purchaser suffers an economic loss of perhaps a few cents; had she known the actual content of the two packages and been able to make an informed purchase, she would have selected the smaller package and received more for her money. Such injuries in monetary terms are no doubt rather insignificant from the point of view of a single consumer. However, frequent offenses in an industry in which over 80 billion dollars of purchases are made annually 11 may involve a considerable economic loss to the consuming public. Whether Conlgress viewed slack filling as an offense to the individual purchaser or to consumers collectively, this economic injury appears to have prompted, at least in part, the legislative finding that remedial action was necessary.

Not only does the consumer suffer an economic loss from slack filling, but proliferation of this practice may also lead to a decline in the consumer's ability to make rational purchases. Everyone is familiar with advertisements designed to appeal to the irrationality of the consumer and, to be sure, many decisions to purchase may not be made rationally. Yet this is no justification for preventing the consumer from making informed, rational choices when he wants to. This objective seems implicit in the Federal Food, Drug, and Cosmetic Act, which contains numerous requirements for disclosure-such as net weight, ${ }^{12}$ use of artificial coloring or flavoring, ${ }^{13}$ and manufacturer's natme and place of business. ${ }^{14}$ The purpose of these requirements obviously is not to pro-

as to the quantity of its contents. It is not misleading or misbranded." $195 \mathrm{~F}$. Supp. at 328. (2) "The available alternative means of packaging claimant's . . . mints are not less deccptive than those actually employed in the accused package." Id. at 330. (3) "The efficacy of claimant's accused package both from the standpoint of protecting the contents and from the standpoint of economy of manufacture, outweighs its alleged deceptive quality." Ibid. The Government's libel was again dismissed; on a second appeal the Third Circuit affirmod per curiam.

10. Quoted in Touluin, The Law of Foods, Drugs and Cosmetics 10 (1942).

11. HEW ANs. Rep. 314 (1961).

12. Section 403 (e), 52 Stat. 1047 (1938), 21 U.S.C. $\$ 343$ (e) (1958).

13. Section 403(k), 52 Stat. 1047 (1938), 21 U.S.C. $\$ 343(\mathrm{k})$ (1958).

14. Section 403(e), 52 Stat. 1047 (1938), 21 U.S.C. $\$ 343$ (e) (1958). 
tect the consumer's health or safety but to give him maximum information upon which to base his decisions to buy. Statutes in other areas ${ }^{16}$ similarly require disclosures designed to promote informed consumer choice. ${ }^{16}$ Legislative insistence that the size of a package accurately reflect its contents seems perfectly consistent with such previous attempts to enlarge the scope of rational consumer decision-making. ${ }^{17}$

It may be argued that this analysis presents a distorted view of the seriousness of the injury to either the individual purchaser or consumers as a group, since the purchaser can ignore the appearance of a package and rely instead on the mandatory statement of net weight ${ }^{18}$ to guide him in his purchase decision. Indeed, for some consumers in some circumstances, the net weight may be an adequate guide to an intelligent purchase; for others, however, this may not be the case. A Government survey of consumer behavior has indicated that a

15. See, e.g., Wool Products Labeling Act of 1939, $\$ 4,54$ Stat. 1129, 15 U.S.C. $\S 68$ (b) (1958) ; Federal Alcohol Administration Act § 5(e), 49 Stat. 982 (1935), 27 U.S.C. § 205 (e) (1958); Automobile Information Disclosure Act § 3, 72 Stat. 326 (1958), 15 U.S.C. \& 1232 (1958); Textile Fiber Products Indentification Act \& 4, 72 Stat. 1719 (1958), 15 U.S.C. \& 70(b) (1958); Fur Products Labeling Act § 4, 65 Stat. 177 (1951), 15 U.S.C. $\S 69$ (b) (1958).

16. The courts, in enforcing legislation directed at such an objective, have further articulated the social value involved. For example, in Kerran v. FTC, 265 F.2d 246 (10th Cir.), cert. denied sib nom. Double Eagle Refining Co. v. FTC, 361 U.S. 818 (1959), an advertiser had not disclosed that his "refined oil" was actually re-refined from used oil. Even though the second-hand oil was equally as effective a lubricant as virgin oil, the court supported the FTC's order of full disclosure. The majority reasoned that the public "is entitled to know the facts ... and ... make its own choice with respect to purchasing. ..." Id. at 248. See also FTC v. Algoma Lumber Co., 291 U.S. 67, 78 (1934); Mohawk Refining Corp. v. FTC, 263 F.2d 818, 821 (3d Cir.), cert. denied, 361 U.S. 814 (1959).

17. A very recent example of congressional concern with rational consumer choice appears in the "truth-in-packaging" bill introduced by Senator Hart as a result of the packaging hearings, supra note 1 . S. 3745, 87th Cong., 2d Sess. (1962). Section 3A(d) of the bill authorizes the FTC to promulgate certain types of regulations when the Commission determines that these will "preserve fair competition ... by enabling consumers to make rational comparisons. ..." When he introduced S. 3745, Senator Hart stated:

This bill is designed to restore rational buying to the market place and to remove to a considerable degree the gantlet of psychological traps, successive confusions and outright deceptions that today's consumer must run whenever he passes down a supermarket aisle.

Such practices operate as a blindfold to prevent consumers from getting the information they need and deserve from the packagers of the products they buy.

108 Cong. Rec. 19265-66 (daily ed. Sept. 24, 1962).

Senator Hart has reintroduced the bill in the 88th Congress, as S. 387, with certain modifications. The most important change is that the FDA would continue to have authority over food and drugs for purposes of the regulations authorized by $\$ 3 A(d)$. The FTC would be authorized to act only where other consumer commodities are involved. 109 Co::C. Rec. 604-07 (daily ed. Jan. 21, 1963).

18. A package is misbranded if it does not bear a label containing "an accurate statement of the quantity of the contents in terms of weight, measure, or numerical count. ..." Federal Food, Drug, and Cosmetic Act § 403(e), 52 Stat. 1047 (1938), 21 U.S.C. § 343(c) (1958). 
significant number of purchases are based largely on size. ${ }^{10}$ Moreover, the net weight may be presented in such a way as to preclude calculation of unit cost by the consumer. ${ }^{20}$ For example, if the larger of two packages contains 10 s 8 ounces and costs 39 cents and the smaller package contains $113 / 4$ ounces of the same commodity and costs 42 cents, which is the better buy? Without a slide rule the calculation is not easy, and the frustrated consumer may well turn to package size as a more useful criterion for choice. Finally, the usefulness of net weight as a criterion depends largely on the objective of the consumer. If a purchaser is primarily interested in the number of units in a package, rather than in the total weight of all the units, size is a very rational guide for selection. For example, a consumer who wants ten half-inch slices of cheese may be more satisfied by a five-inch carton than by a three-inch carton even though the smaller package has a greater net weight than the larger. In an analogous situation the Supreme Court has acknowledged that consumers are often influenced by the appearance of a package and that, as a consequence, truthful labeling alone may not provide adequate protection for the bulk of the consuming public. $^{21}$ This fact, the Court noted, presented an ample basis for congressional provision for standards of identity ${ }^{22}$ to supplement the disclosure of ingredients. ${ }^{23}$ Under such standards, a packager cannot, for example, call his product "canned peas" if the can contains other than specified types of peas, even though the presence of the non-conforming peas is clearly disclosed on the label. ${ }^{24}$ Similarly, the realities of consumer behavior in response to package size ${ }^{25}$ suggest that Congress had an equally sound basis for supplementing the disclosure of net weight with a guaranty to the consumer that the size of a container is reasonably indicative of the quantity. ${ }^{26}$

A second argument attempting to minimize the seriousness of the injury from a less-than-full package is that the offended consumer has a potent sanction in his ability to refuse a second purchase of the offending package. If the purchaser, once deceived, continues to buy the product, he cannot claim a new

19. The survey is discussed in $180 \mathrm{~F}$. Supp. at $866 ; 197 \mathrm{~F}$. Supp. at 327 ; Brief for Appellant, p. 8, United States v. 174 Cases of Delson Thin Mints, 302 F.2d 724 (3d Cir. 1962).

20. Cf. Packaging Hearings 103.

21. Federal Security Adm'r v. Quaker Oats Co., 318 U.S. 218, 230-31 (1943). Sec also United States v. Carolene Prod. Co., 304 U.S. 144, 149-50 (1938); United States v. 306 Cases, 55 F. Supp. 725, 726 (E.D.N.Y. 1944), aff'd sub nom. Libby, McNeill \& Libby v. United States, 148 F.2d 71 (2d Cir. 1945).

22. Federal Food, Drug, and Cosmetic Act $\S 401,52$ Stat. 1046 (1938), as amended, 21 U.S.C. § 341 (1958). See FDA, What Consumers Should Know About Food Standards 5-7 (Publ. \#8) (1962). The standards of identity which have been promulgatcd by the Secretary of Health, Education, and Welfare appear in 21 C.F.R. (Subchap. B, 1955 \& 1962 Supp.).

23. Federal Food, Drug, and Cosmetic Act $\S 403(i), 52$ Stat. 1048 (1938), 21 U.S.C. §343(i) (1958).

24. 21 C.F.R. $\S 51.1$ (1955 \& 1962 Supp.).

25. See text accompanying note 19 supra.

26. See note 53 infra. 
injury with each purchase since he knows that the package will not be full. Despite the apparent persuasiveness of this argument, it rests upon two unwarranted assumptions. First, it assumes that the consumer is always able to verify the quantity that he received when he made his initial purchase. Yet, some products, such as those in aerosol form, offer no meaningful possibility of quantity verification even after purchase, for an attempt to measure the contents of an aerosol container necessarily destroys its usefulness. Second, the argument erroneously assumes that the offending packager will always have competitors who offer packages which are not slack-filled. The manufacturer of a package which competes with a slack-filled container may be seriously damaged if purchasers reject his package or shift to his competitor's container because of its larger size, and it may not be economically feasible for him to wait for a subsequent round of purchases when disgruntled buyers of the slackfilled package may choose his product. Instead, the manufacturer may decide to curtail or forestall injury by adopting his competitor's tactics.27 As an increasing number of packagers slack-fill, whether in response to competition or on their own initiative, the availability to the consumer of acceptable substitutes steadily decreases.

To some extent, modern techniques of food marketing account for these economic and non-economic injuries to the consumer. In the age of the supermarket, as the testimony at the packaging hearings ${ }^{28}$ made clear, the package is no longer a mere passive container but has replaced the human salesman in the actual selling process. ${ }^{29}$ Indeed, packaging experts believe that the visual impact of a container is the central element in determining its effectiveness as a "salesman."30 Because of the highly competitive atmosphere of the supermarket aisle, ${ }^{31}$ some manufacturers have tended to increase the size of their package without increasing the quantity of its contents, so that their product will " 'reach out' from the blur of boxes"32 more effectively than their competitors'. The larger package obviously provides more surface area on which a product name or trademark, art work, selling claims, and other information

27. Testimony at the Delson trial indicated that certain candy manufacturers adopted the hollow dividers and end pieces solely to meet competition. Brief for Appellant, p. 7, United States v. 174 Cases of Delson Thin Mints, 302 F.2d 724 (3d Cir. 1962).

28. See note 1 supra.

29. Packaging Hearings 10, 194, 902. See also Paraffined Cartos Reseascir Councri, The Man IN the Package 3 (1957). One witness at the hearings went so far as to suggest that "[ $t]$ oday, advertising and packaging are synonymous." Testimony of Roy King, editor of "Food Field Reporter," Packaging Hearings 194.

30. See Paraffined Carton Research Council, op. cit. sippra note 29, at 10-13; Irstitute for Mottvational Research, Integrated Package Resenrce Bull. No. 6 (undated).

31. A 1959 duPont study of consumer buying habits noted that the average number of items on the shelves of a typical supermarket was then 5,660. Packaging Hearings 551 . Larger figures were mentioned throughout the hearings. Senator Hart, in a concluding statement, put the number at 7,500 and noted that various witnesses had foreeast that within a decade 20,000 items will be arailable. Id. at 902.

32. Paraffined Carton Researca Councti, op. cit. supra note 29 , at 10. 
can appear and thus more readily attracts the consumer's eye. Moreover, because many consumers are guided in their purchases by the size rather than by the price of a container, ${ }^{33}$ a larger package frequently outsells its smaller counterpart, regardless of how much product it actually contains. The distribution of such slack-filled packages in order to secure a competitive advantage does not appear to benefit the consumer in any way; in fact, the competitive advantage, accompanied by injuries to the consumer, arises only if the deception is effective. If all instances of slack filling could be explained solely in terms of packager activities of this sort, then they would appear to be totally unjustified. Under such circumstances no slack-filled package ought to escape condemnation.

However, the problem does not yield to so simple an analysis, for the Delson case and the packaging hearings identified two other explanations ${ }^{84}$ for slack filling which frequently involve benefits for consumers. One of these explanations, with which the Delson case was directly concerned, involves product protection and preservation. Certain types of products need cushioning to protect them against breakage during handling and shipment. This cushioning, or other similar means of protection, will necessarily fill part of the package. ${ }^{35}$ Likewise, some packages contain additional devices, such as multiple interior wax packets, to keep part of the product fresh while another part is being consumed. Clearly, these devices also occupy some interior space $;^{80}$ as a result, the benefit that they provide is inevitably accompanied by a less-than-full package.

The secondsexplanation for slack filling which may be associated with consumer benefits involves machine packaging. Mechanical handling and processing may yield economies of scale that drastically reduce the cost to the consumer of many food items. ${ }^{37}$ They may also be partly responsible for the marketing of products in a variety of quantities and in various stages of preparation, ${ }^{38}$ thus increasing the range of consumer choice and perhaps effecting additional economies for the consumer by preventing waste. Yet, because of technological problems, slack filling may inevitably accompany these bentefits of machine packaging. For instance, the speed of packaging lines may not allow enough time for contents to settle before the package is sealed. Further" more, high-speed packaging lines must be designed for the type of package

33. See text accompanying note 19 supra.

34. In addition to the explanations for slack filling discussed in the text, still another is sometimes offered, namely, that small items must be packaged in large containers to prevent pilferage. See Packaging Hearings 146, 203-04. This explanation applies only to a few products.

35. See id. at $146,235,310$.

36. See id. at 85, 776. Cf. United States v. 738 Cases of Jiffy-Lou Vanilla Flavor Pudding, 71 F. Supp. 279 (D. Ariz. 1946).

37. See U.S. Dept. of Labor, How American Buying Habits Change 103.05 (1959); N.Y. Times, Nov. 13, 1962, p. 53, col. 4. Cf. United States v. 116 Boxes of Arden Assorted Candy Drops, 80 F. Supp. 911,913 (D. Mass. 1948).

38. Cf. U.S. DePT. of LaBOR, op. cit. supra note 37 , at 105,120 ; N.Y. Times, sulpra note 37. 
they are to handle, but because of their costliness, the same machines must frequently be used to package different products. Consequently, products of various densities may be packaged in the same size container and may settle differently. ${ }^{39}$ Mechanical vibration is used to obtain some settling during the filling process and to minimize empty space, but to duplicate completely the settling that occurs during shipment would require slowing the machines to an inefficient rate..$^{40}$ Moreover, various types of containers require the presence of some space after filling to permit proper sealing. ${ }^{41}$ Overfill, for example, makes it difficult to assure enough internal vacuum to keep the ends of a can drawn tightly. ${ }^{42}$ Space must also be left in cartons so that internal wrappers can be folded and sealed. Finally, to permit machine handling without damage, some canned foods must be sealed in their containers before being processed at high temperatures. Some empty space may be necessary to insure proper heat penetration and sterilization ${ }^{43}$ and to allow expansion of the product. ${ }^{44}$

Admittedly, slack filling-whatever its explanation-involves injury to the consumer, perhaps in economic terms and surely by restricting his ability to make fully informed purchase decisions. ${ }^{45}$ Yet, where there are concomitant benefits for the consumer, ${ }^{46}$ these ought not to be ignored in the establishment of a regulatory scheme. To focus solely on the possible injuries from slack filling overlooks the fact that purchasers may actually be willing to lose a few pennies or to relinquish some of their ability to make rational choices in order to have more or better or cheaper products among which to choose. The nation's packagers, of course, have made the initial choice for the consumer: they have chosen to provide the benefits and permit the injuries. Indeed, that choice may in fact not reflect consumer desires; but unless one is certain that the consumer and the packager are at odds, any scheme for regulating slack filling ought to seek a more balanced result than the absolute proscription of less-than-full packages. Regulatory standards should satisfy a criterion of discrimination between those instances of deception which are tolerable because they are inextricably associated with benefits to the consumer and those instances of deception which involve no more than an attempt by a packager to secure a competitive advantage at consumer expense. The rationale for this criterion may be clarified by an analogy to cases of private nuisance. In such cases, the question of whether a particular use of property, which inflicts injury on adjoining property owners, should be enjoined depends upon the social value of that use in the light of available alternatives. Slack filling calls for a

39. See Packaging Hearings 420, 645-46.

40. See id. at 143, 146, 896. See United States v. 116 Boxes of Arden Assorted Candy Drops, 80 F. Supp. 911, 912 (D. Mass. 1948).

41. See Packaging Hearings at 381, 421, 645-46.

42. Letter from C. A. Greenleaf, Asso. Director, Research Laboratories, National Canners Ass'r, to the Yale Law Journal, Oct. 11, 1962, on file in Yale Law Library.

43. Ibid.

44. See Packaging Hearings 332.

45. See text accompanying notes 10-17 supra.

46. See text accompanying notes 34-38 supra. 
similar examination of the social utility of a packager's conduct in light of both the injuries that his technology causes and of the alternative packaging techniques which are available to him. ${ }^{47}$

The Third Circuit's decision in Delson, the only case establishing standards for the application of section 403 (d), indicates that this provision permits an inquiry into possible justifications for slack-filled packages. The court stated that section 403 (d) requires an initial showing by the Government that the accused container is deceptive to the "ordinary purchaser of this type of merchandise." ${ }^{\prime 8}$ If the Government makes out a prima facie case of deception, the claimant may then attempt to show the necessity, in view of available alternative techniques, of particular safety features in the accused package which justify its deceptive qualities. ${ }^{49}$ Thus, the Delson case properly makes available to the packager of a slack-filled container a defense based on product protection. However, as noted earlier, ${ }^{50}$ product safety is not the only explanation for slack filling which may be associated with benefits for the consumer. It is equally important to provide packagers with an opportunity to justify their less-than-full containers in terms of machine efficiency. Does the construction of section 403 (d) in Delson leave room for such a presentation? The Third Circuit, in accepting the standard for deception established in an earlier slack filling case, ${ }^{51}$ appears to have recognized that such a defense would be available, since the earlier decision, ${ }^{\text {b2 }}$ in articulating that standard, had expressly re* ferred to congressional intent to provide for the exigencies of machine packaging. ${ }^{53}$ More importantly, the reasoning of the Third Circuit, supporting its

47. A private tort action, based upon a theory of deceit or fraudulent misrepresentation, would probably be available to a purchaser injured by a slack-filled package. Since a plaintiff in such an action must prove an intent to deceive on the part of the defendant packager, this tort theory would appear to be sensitive to defenses of machine efficiency and prodict protection. Thus, it would satisfy the criterion proposed in the text. Nevertheless, even if a purchaser could readily establish his financial loss, it would seldom, if ever, be worthwhile for him to bring an action for recovery. In any individual case involving a slack-filled package, the pecuniary damage would be negligible. Moreover, since injury to feelings is not compensable in an action for deceit, the damage to a purchaser's ability to make rational choices would probably not provide an alternative ground for recovery. The possibility of punitive damages also would seem to be an inadequate incentive for a suit in which the actual damage is so slight. For a complete discussion of fraudulent misrepresentation, sec 1 Harper \& Jamies, The Law of Torts ch. VII (1956) ; Prosser, Law of Torts ch. 18 (2d ed. 1955). The measure of damages for misrepresentation is discussed in McCommck, LAW OF DaArages $\S \S 121-22$ (1935).

48. 287 F.2d at 247, quoting United States v. 116 Boxes of Arden Assorted Candy Drops, 80 F. Supp. 911,913 (D. Mass. 1948); and see text accompanying note 10 supra.

49. $287 \mathrm{~F} .2 \mathrm{~d}$ at 248.

50. See text accompanying note 34 supra.

51. 287 F.2d at 247. See note 9 supra.

52. United States v. 116 Boxes of Arden Assorted Candy Drops, 80 F. Supp. 911 (D. Mass. 1948).

53. Id. at 913. The court's reference was to the Senate reports on the food and drue bill. One of these reports stated:

[Section $302(d)$ ] is intended to reach abuses which have arisen in the packaging of food through the use of deceptively shaped, formed, or colored containers or 
conclusion that safety factors in a package might justify quantitative deception, would surely lead to acceptance of other technological defenses. ${ }^{\text {th }}$ Indeed, the court explicitly suggested that product protection was not the sole justification that a packager could offer. It stated that a claimant might show that, in addition to consumer expectations, "other considerations such as [safety features]" were relevant to a determination of the legality of a particular less-than-full package.55

Thus, section 403 (d), as construed by the court in Delson, appears to offer adequate scope for a balanced treatment of conflicting consumer interests and to provide an effective means for regulating the use of slack-filled packages. But the FDA's resort to this provision has been quite limited; only four cases based on section 403 (d) have been brought to court. FDA $^{57}$ has indicated that it intends to rely more extensively on another section of the Federal Food, Drug, and Cosmetic Act, section 401, which provides a quite different scheme of regulation for slack filling. ${ }^{.8}$ An examination

through deceptive methods of packing. Packages only partly filled create a false impression as to the quantity of food which they contain despite the declaration of quantity of contents on the label. This provision is not intended to authorize action against packages of food which are filled as full as practicable in good manufacturing practice, even though shrinkage may occur after the products are shipped.

S. Rep. No. 361, 74th Cong., 1st Sess. 9 (1935). Section 302(d), referred to in the preceding report, was the predecessor of $\S 403$ (d), the section involved in the Delson case. The renumbering occurred when the food-and-drug bill was re-introduced in the 75th Congress, having died in the 74th.

Although no explicit congressional concern for product protection appears in the legislative history of $\S 403$ (d), Congress may nevertheless have intended the FDA to malie allowance for safety features in packages when applying those provisions of the Act which deal with the amount of product in a container. This possible intent is suggested by $\S 401$, which states in part:

.... In prescribing any standard of fill of container, the Secretary shall give due consideration to ... need for the necessary packing and protective material.

52 Stat. 1046 (1938), as amended, 21 U.S.C. $\$ 341$ (1958). The "standard of fill" mentioned in this provision will be discussed in detail infra.

54. See 287 F.2d at 248.

55. Id. at 248. (Emphasis added.)

56. Delson was the fourth case brought under $\S 403$ (d). The previous three cases are cited in note 5 supra.

57. The FDA is not the only federal agency which is empowered to regulate slack filling. The FTC has applied § 5(a)(1) of the Federal Trade Commission Act, which proscribes "unfair or deceptive acts or practices in commerce" to slack-filled containers of both food and non-food products. Section 5(a) (1), 52 Stat. 111 (1938), as amended, 15 U.S.C. $\S 45(a)$ (1) (1958). Since 1954, however, the FTC has not exercised its powers in the food and drug field, having reached a working agreement with the FDA. The agreement gives the FTC primary responsibility for advertising (other than labeling) in the food and drug field, while it assigns to the FDA primary responsibility for misbranding, which includes slack filling, in that area. The text of the agreement appears in Packaging Hearings 827-29.

58. Letter from William W. Goodrich, Assistant General Counsel, Food and Drug Division, HEW, to the Yale Law Journal, Oct. 30, 1962, on file in Yale Law Library. See also letter from Wallace F. Janssen, Director, Division of Public Information, FDA, to the Yale Law Journal, Oct. 18, 1962, on file in Yale Law Library. 
of this scheme will provide a basis for evaluating the relative merits of the two provisions.

Section 401 provides:

Whenever in the judgment of the Secretary such action will promotc honesty and fair dealing in the interest of consumers, he shall promulgate regulations fixing and establishing for any food, under its common or usual name so far as practicable ... . reasonable standards of fill of container....59

Under this section the FDA, rather than proceeding against particular deceptive packages, formulates standards of fill for complete product lines. Containers which conform to these standards would not, of course, be stubject to a seizure action under section 403(d). Packager justifications for consumer deception are appropriately accounted for under the fill-standard provision. Indeed, factors such as product protection and machine efficiency must be considered in the very process of establishing standards of fill. Consequtently, the standards are ordinarily set in terms which are appropriate only for a specific product line.60 For example, the fill standard for pineapple juice may call for a can to be 90 per cent full, ${ }^{61}$ while the fill standard for candy bart's may be set in terms of the ratio of the bar to its cardboard "boat."

The FDA has established some fill standards under section 401, but thus far these have been restricted to certain canned foods. ${ }^{03}$ The limited use of this provision reflects the fact that the advantages of this regulatory clevice-its flexibility and objectivity-create appreciable administrative burdens. The variety of technical problems involved in packaging and the cliversity of packaged products make any attempt to establish generalized fill standards wholly unrealistic. ${ }^{64}$ The enormous number of items on the average super-

59. 52 Stat. 1046 (1938), as amended, 21 U.S.C. $\$ 341$ (1958).

60. Senator Hart's "truth-in-packaging" bill, supra note 17, also provides for the possible use of fill standards. Letter from Philip A. Hart, U.S.S., to the Yalc Laze Journal, Dec. 6, 1962, on file in Yale Law Library. Section 3A(d) (2) authorizes the FTC to promulgate regulations which will

prevent the distribution of [particular commodities] . . . for retail sale in packages of sizes, shapes, or dimensional proportions which may deceive retail purchasers as to the weight, quantity, or number of the contents thereof.

S. 3745, 87th Cong., 2d Sess. (1962). Section 3A(d) of this bill requires a product-line approach to the regulatory activities authorized by its subsections. Introducing the bill, Senator Hart explained that "such regulations must be applied on a product-by-product basis. Obviously, many directives that would be sensible for soap packagers would look silly if enforced on fish canners or ice cream manufacturers." 108 CoNG. Rec. 19266 (daily cd. Sept. 24, 1962).

61. 21 C.F.R. \& 27.56 (Supp. 1962).

62. In Canada-under the Food and Drugs Act, 1953, 2 Eliz. II c. 38, \& 5.(1) (Can.)Trade Information Letter No. 168 was issued on Mar. 20, 1959, by the Food and Drugr Directorate, establishing such a standard of fill for wrapped chocolate and candy bars.

63. The FDA has established standards of fill for fifteen types of canned foods (certain fruits, vegetables, and fish). 21 C.F.R. pts. 27, 36, 37, 51, 53 (1955 \& 1962 Supp.).

64. Spokesmem for various facets of the food industry have supported the fill standard approach but all agree that the standards must be particularized. See Packaging Hearings $83,88,421,683-84,776$. At least one important trade group, Cereal Institute, Inc., has begun 
market shelf and the projected growth of this number ${ }^{65}$ have led FDA Commissioner Larrick to view the extensive use of individualized fill standards, set by the FDA, as a "monumental undertaking." Many fill standards require substantial testing and experimentation in order to determine their acceptability; such standards cannot be set in isolation from the actual pachaging process. ${ }^{67}$ Still other standards, while perhaps not involving a comparable degree of initial experimentation, might at least require re-examination with each change in technology or innovation in packaging.

Although the FDA's reluctance, at least in the past, to devote its resources to this substantial task of regulation is understandable in view of its other responsibilities, ${ }^{68}$ alternative procedures are not necessarily foreclosed. Various industries, for example, might assume the responsibility for setting standards for their own product lines, which standards could then be submitted to the FDA for approval. ${ }^{69}$ The FDA could, of course, deny approval of or challenge any industry-set standards which seemed unnecessarily lenient in relation to the requirements of machine efficiency and product safety and, further, could set the standards where an industry was reluctant to take upon itself the task. Spokesmen for the packaging industry point out that packager participation would permit industry members to apply their knowledge of relevant technical problems to the establishment of standards. ${ }^{70}$ Industry-government cooperation of this sort is by no means new; the FDA has in the past consulted with manu-

a study program aimed at the voluntary establishment of fill standards for its own members. During 1961-62 the Legal and Technical Committee of the Institute studied the matter of package fill for cereal cartons. A memorandum entitled "Pachage Fill of MIultiple Serving Cereal Cartons" was presented to the Executive Committee of the Institute on Oct. 3, 1962, together with a Committee report indicating that the proposed method of measuring fill was fairly satisfactory but had certain shortcomings associated with sampling procedures. The consensus of the Executive Committee was that it did not appear fersible to cstablish standards of fill for breakfast cereal packages at that time because of the sampling problems indicated in the Committee report. Letter from E. L. Harding, Chairman; Legal and Technical Committee of Cereal Institute, Inc, to the Yale Law Journal, Nov. 1, 1962, on file in Yale Law Library.

65. See note 31 supra.

66. Packaging Hearings 801. Commissioner Larrick blamed the magnitude of this task on the "lack of standardization of the sizes of containers themselves." Ibid.

67. For example, a standard for canned peas may arbitrarily be set at $95 \%$ of complete fill, but in meeting this standard a high-speed filling machine may scatter enough peas on the cannery floor to erase most of the monetary savings obtained through the use of mechanical packaging techniques. An acceptable standard, it would seem, ought to take account of existing technology; hence, the need for experimentation suggested in the text.

68. The FDA in the past decade has tended to allocate most of its appropriations to the enforcement of health and safety regulations and to give only limited attention to the economic provisions of the Federal Food, Drug, and Cosmetic Act. HEIV Ass. REP. 200 (1954) ; HEW ANN. Rep. 167 (1955) ; HEW ANw. Rep. 207 (1956) ; Paclaging Hcarings 797. In recent years, however, enforcement activity in the area of "pocket-book protection" has been stepped up somewhat. HEW ANN. REP. 199 (1957) ; HEW Awr. REP. 200 (1959).

69. If approved, the standards would be promulgated under $\S 401$ by the Secretary of Health, Education, and Welfare. See text accompanying note 59 sipra.

70. See Packaging Hearings 932, 947. 
facturers for the purpose of establishing standards, and Commissioner Larrick has expressed the FDA's present approval of this cooperative procedure. ${ }^{71}$

In addition to the complexities involved in promulgating standards of fill, ${ }^{72}$ the fill-standard approach presents considerable problems of enforcement which are partly attributable to the great variety of food products. Some items, whose slack-fill is "built in" at the time of packaging, rather than resulting from settling during shipment, would present relatively little difficulty. For example, given the fill-standard for candy bars (ratio of bar to "boat"), ${ }^{73}$ it would be simple to determine the acceptability of a particular bar. Most packages involving safety devices and some machine-packed products thus could easily be policed at any point in the distribution process. However, those machine-filled packages in which slack filling results from conditions encountered during shipment present greater problems. Because it is impossible to forecast the amount of settling (from vibration or breakage) that will actually occur after some containers leave the packager's plant, a fill-standard requiring cereal boxes, for example, to be 90 per cent full on the retailer's shelf is unrealistic. ${ }^{74}$ On-site supervision of packaging operations at thousands of plants, however, would involve vast expense. A more economical approach might be for the FDA to undertake periodic review of statistical quality control ${ }^{75}$ records which could be mandatorily kept by packagers whose products are subject to variable in

71. Id. at 800-01. The Citizens Advisory Committee, in its October 1962 REroks To the Secretary of Health, Education, and Welfare on the Food and Duug AdminisTRATION strongly urged that industries assume greater responsibility for self-regulation, in cooperation with the FDA. REPORT at I-12. The report is reprinted in 17 Food Drua CosM. L.J. 581-717 (1962). Senator Hart's "truth-in-packaging" bill, supra note 17, also conten1plates industry-government cooperation. Section 3A(e)(1), S. 3745, 87th Cong., 2d Sess. (1962). The FTC, for some time, has consulted with industry representatives when setting standards for various trade practices. The regulations and procedures for FTC Trade Practice Conferences appear in 16 C.F.R. $\$ 16.1$ (1960).

72. The potential need for hearings on controversial standards and the possibility of appeal to the courts by parties adversely affected by a particular standard must not be overlooked. Such proceedings are provided for by Federal Food, Drug, and Cosmetic Act \& 701 (e), 52 Stat. 1055 (1938), as amended, 21 U.S.C. $\S 371$ (e) (Supp. III, 1962).

73. See note 62 supra and accompanying text.

74. Cf. memorandum of the Legal and Technical Committee of Cereal Institute, Inc, stipra note 64 .

75. Statistical quality control programs, basically involving the application of statistical sampling techniques, take many forms. In highly simplified terms, a statistical cuality control program may operate in the following way: From a selection of sample container's taken from the packaging line, control charts provide graphic and statistical information concerning actual deviation from an ideal percentage of fill. The compilation: of such data from a mathematically determined optimum sampling lot size will provide a model which acts as a control for the plant's filling operations. Thereafter, additional samples are periodically taken from the line and compared as a group with the control chart. Deviations from an acceptable distribution are readily discernible and alert the packager to the need for adjustment of his equipment. Quality control programs have regularly been used with substantial success by many packagers in order to control different types of packaging variations. Cf. Filice, Quality Control Techniques Available to the Average Canter, National Canners Association Information Letter (No. 1764), Jan. 30, 1960; Way, Fill Control in the Canning Industry, American Society for Quality Control (ASQC) National 
fluences, such as settling, after they leave the plant. ${ }^{70}$ Sanctions would be imposed where deviations from the fill-standard exceeded applicable tolerances. ${ }^{77}$

Thus, it seems clear that both section 403 (d) and section 401 offer regulatory schemes capable of striking an appropriate balance between conflicting consumer desires for truth and for technologies which may necessarily preclude that truth. In theory, comprehensive use of fill-standards would probably maximize both consumer protection from deceptive packaging and the ability of manufacturers to predict the legality of their containers. Yet, there are important considerations which militate against such extensive use of the fill-standard technique. First, the inevitable expenditures involved in their promulgation and enforcement suggest that it would be unwise to indiscriminately expand the program in the absence of more accurate estimates of consumer damage than are presently available. Rather, the use of fill standards might more appropriately be

Convention Transactions 505, 508 (1955). See also Stier, How Statistical Quality Control Is Used in Food Processing Industries, ASQC National Convention Transactions 663, 665 (1959). See also, a discussion of the remarkable technology of weight and fill control in Modern Packaging, June 1962, p. 103.

76. The Citizens Advisoty Committee on the FDA, in its REPORT, supra note 71, noted the unreality of an inspector in every plant and called for a more constructive approach to regulation. Id. at I-9. The Committee recommended less FDA emphasis on punitive activity and greater efforts to create "a proper climate . . . within industry" so that "[m] andated self-inspection" can play a significant role in consumer protection. Id. at I-10. With respect to standards of fill, in particular, the Committee recommended that

The FDA should be relieved of the responsibility for such activities as policing container fill ... by turning these matters over completely to state and local agencies to be conducted in accordance with FDA standards.

Id. at III-10.

77. Fill standards can be used in various ways to minimize consumer deception. One approach would be to prohibit the distribution of all containers which do not meet the prescribed standards. Such proscription of all non-standard products is the technique used to enforce standards of identity (see text accompanying notes 22-24 supra). If a paclagger wishes to distribute a product not conforming to a standard of identity, the common name authorized by the relevant standand cannot be used, and all ingredients must be disclosed on the label. Section 403 (g), 52 Stat. 1047 (1938), 21 U.S.C. $\$ 343(\mathrm{~g})$ (1958).

Alternatively, the distribution of containers which do not meet the preseribed standards of fill could be permitted as long as the fact of substandard fill is disclosed by means of a specified declaration on the label. Existing fill standards use this technique. For example, the standard of fill for pineapple juice contains the following provision:

"If canned pineapple juice falls below the standard of fill of container preseribed in paragraph (a) of this section, the label shall bear the statement of substandard fill specified in $\S 10.3$ (b) of this chapter, in the manner and form therein specified.

21 C.F.R. \& 27.56(b) (1962 Supp.). Section 10.3(b), mentioned in the foregoing provision, states:

The term "general statement of substandard fill" means the statement "Below Standard in Fill" printed in Cheltenham bold condensed caps. ...

21 C.F.R. \& 10.3(b) (1956). This section also contains additional directions for display of the prescribed statement.

Packages which do conform to fill standards might further reduce deception through various forms of affirmative disclosure. For example, a package might bear a statement indicating that it satisfies a standard requiring a stated percentage of fill, or a container might be required to bear a pictorial representation of its interior. The latter would be appropriate, for example, where the contents are wrapped in multiple packets. 
limited to particular types of products which have demonstrated their offensiveness by generating numerous complaints to the FDA. Consumer groups, competitors, food retailers, and other interested parties could easily provide the FDA with information about particularly flagrant instances of slack filling, which would lead to the establishment of a fill standard for the product-line involved. Indiscriminate extension of fill standards is also undesirable because of the restrictions such standards necessarily place on variations among packager techniques and because of the obstacles which they may pose to technological experimentation and innovation. Although applying only to a particular product line, a fill standard inevitably imposes some standardization upon the available methods for packaging that product. Furthermore, fill standards often require substantial preliminary study. ${ }^{78}$ Thus, changes may be difficult to accomplish, both because of the investment of time and resources in the existing standard and because the procedure for bringing about such changes may in itself be time-consuming..$^{70}$

Consequently, although the FDA has indicated an intention to increase its reliance on fill standards, ${ }^{80}$ these limitations suggest that section 403 (d) should not be ignored in dealing with the problem of slack-filled packages. Since section 403 (d) is applied on a case-by-case basis, no particular packaging technique is required. Hence, manufacturers remain free to innovate and to provide the consumer with the opportunity to select, in the market-place, the type of package that he finds most satisfactory. The ability of the FDA, under section 403(d), to focus upon a single firm or a single product is also important. In an industry in which only one packager has generated complaints while others have caused no consumer dissatisfaction, the FDA can proceed against this single offender without having to establish an across-the-board fill standard for the entire product line. Desirable flexibility for the industry can thus be maintained at the same time that undesirable practices are weeded out. Moreover, the potent sanction of section 403 (d), seizure and condemnation of all packages found to be unjustifiably deceptive, represents a significant deterrent both for the packager involved in a particular proceeding and for other packagers who might be tempted to engage in such unacceptable practices. Finally, section 403(d) places much less of a burden on the FDA than fill standards. As suggested earlier, consumer groups and others can make the discovery of deceptive practices easy; once sufficient complaints have been lodged, the FDA, after a preliminary examination, can institute a condemnation proceeding. As Delson has made clear, the FDA need only establish that a package is deceptive to the ordinary consumer. In a section 403 (d) proceeding, product protection and machine efficiency justifications for slack filling represent affirmative defenses to the charge of deception. Thus, the burden of proof is on the manufacturer, who is in the best position to present relevant information concerning his packaging techniques and upon whom, given the objectives of slack-fill regulation, such burdens properly lie.

78. See note 67 supra and accompanying text.

79. See note 72 supra.

80. See noțe 58 supra and accompanying text. 